\begin{tabular}{c|c|c}
\hline JURNAL PENELITIAN FARMASI HERBAL & VOL. 1 NO. 2 & $\begin{array}{c}\text { EDITION: NOVEMBER 2018 - } \\
\text { APRIL 2019 }\end{array}$ \\
\hline RECEIVED: 17 FEBRUARI 2019 & http://ejournal.delihusada.ac.id/index.php/JPFH \\
\cline { 2 - 3 } & REVISED: 18 MARET 2019 & ACCEPTED: 20 APRIL 2019 \\
\hline
\end{tabular}

\title{
DEPRESI INDUCED STEROID: STUDI KASUS
}

\author{
Saiful Batubara dan Julahir H. Siregar \\ Universitas Islam Sumatera Utara, Jl. STM, No. 77, Medan \\ Email: saiful.batubara@fk.uisu.ac.id
}

\begin{abstract}
Back Ground: Depression is a natural disturbance of feeling that is characterized by feelings of sadness, loss of interest and easily tired. Steroids are drugs that can reduce swelling, pain and heat due to inflammation through reducing the immune response. Steroids are often used in cases of systemic Lupus Erythematosus in the long term. Therefore management of the disease must be done well because steroids can cause depression. Case Report:Women, 37 years old, depressed mood, disappointment in life, loss of enthusiasm, fatigue, decreased appetite and difficulty sleeping for 1 year. 4 years ago I took steroids for 2 years at a dose of 20mg / day, because rheumatoid arthritis was stopped by os, and for the past 1 year, steroid consumption was due to Systemic Lupus Erythematosus around $60 \mathrm{mg} /$ day. . Before the os consumes steroids, the OS has never experienced depression.BP: $110 / 70 \mathrm{mmHg}, H R 88 x /$ menit, RR $20 x /$ menit, Temp $37^{\circ} \mathrm{C}$. Skor BDI 21. Laboratorium Hb 11,8 g/dl, Leukosit 7500/mm , trombosit 201.000/mm3, Kalium 2,8, KGDad 99 mg/dISGOT 29 ,SGPT32, Ureum 15,78 mg/dl, Creatinin $0,65 \mathrm{mg} / \mathrm{dl}$. Tot Colesterol 198mg/dl, LDL $128 \mathrm{mg} / \mathrm{dl}, \mathrm{HDL} 35 \mathrm{mg} / \mathrm{dl}$ Fototoraks : Jantung dan Parudalambatas normal, FotoLumbosakral : SpondilosisLumbalis. The patient is diagnosed with depression. Given psychotherapy, sandepril $2 \times 25 \mathrm{mg}$ for 3 months. Patients show clinical improvement marked by reduced sadness and can understand the disease. Conclusion :Steroid-induced depression has been reported after psychotherapy and sandepril $2 \times 25 \mathrm{mg}$ of the patient's condition showed improvement.
\end{abstract}

Kata Kunci: Depresi, Steroid, RhematoidAthritis, Sistemik Lupus Eritematosus.

\section{LATAR BELAKANG}

Penggunaan kortikosteroid saat ini sangat umum dan luas digunakan untuk pengobatan pada berbagai kasus penyakit imunologi dan penyakit inflamasi seperti sistemik lupus eritematosus, vasculitis, asma, penyakit paru obstruksi kronik, nyeri dan berbagai penyakit lainnya. Ternyata penggunaan steroid memberikan masalah efek samping. Depresi merupakan salah satu efek samping yang terjadi pada pemakaian steroid, seperti pada penyakit SLE yang memakai steroid sebagai terapinya, dimana dipakai dosis yang besar.

Depresi adalah gangguan alam perasaan yang ditandai adanya perasaan sedih, hilang minat dan mudah lelah. Ada beberapa cara penegakan diagnosis depresi menurut DSM-IV atau menurut ICD-10. Menurut DSM-IV criteria depresi berat mencakup 5 atau lebih gejala berikut, dan telah berlangsung 2 minggu atau lebih, yakni: Perasaan depresi; Hilangnya minat atau rasa senang hampir setiap hari; Berat badan menurun atau bertambah yang bermakna; Insomnia atau hypersomnia hampir setiap hari; Agitasi atau retardasi psikomotor hampir setiap hari; Kelelahan (rasa lelah atau hilangnya energi) hampir setiap hari; Rasa bersalah atau tidak berharga hamper tiap hari; Sulit konsentrasi; Pikiran berulang tentang kematian atau gagasan bunuh diri (Mudjaddid, 2009; Reus, 2012)

Gejala-gejala tersebut diatas seharusnya menimbulkan gangguan klinis yang bermakna dalam kehidupan individu. Dalam menegakkan diagnosis, gejala perasaan depresif dan atau hilang minatnya harus ada. Penggunaan DSM IV mungkin tidak spesifik, dan dianjurkan dengan menggunakan ICD-10.

Menurut ICD-10 gejala-gejala depresi terdiri dari Gejala Utama, yakni: Perasaan depresif; 


\begin{tabular}{c|c|c}
\hline JURNAL PENELITIAN FARMASI HERBAL & VOL. 1 NO. 2 & $\begin{array}{c}\text { EDITION: NOVEMBER 2018 - } \\
\text { APRIL 2019 }\end{array}$ \\
\hline RECEIVED: 17 FEBRUARI 2019 & http://ejournal.delihusada.ac.id/index.php/JPFH & ACCEPTED: 20 APRIL 2019 \\
\cline { 2 - 3 } & REVISED: 18 MARET 2019 & ACE
\end{tabular}

Hilangnya minat dan semangat; Mudah lelah dan tenaga hilang; Gejala lain, yakni: Konsentrasi menurun; Harga diri menurun; Perasaan bersalah; Pesimis terhadap masa depan; Gagasan membahayakan diri (self harm) atau bunuh diri; Gangguan tidur; Gangguan nafsu makan; Menurunnya libido (Kaplan, 2000; Sharp, 2002).

Tabel 1. Penggolongan Depresi menurut ICD 10

\begin{tabular}{|l|l|l|l|l|}
\hline $\begin{array}{l}\text { Tingkat } \\
\text { Depresi }\end{array}$ & $\begin{array}{l}\text { Gejala } \\
\text { Utama }\end{array}$ & $\begin{array}{l}\text { Gejala } \\
\text { lain }\end{array}$ & Fungsi & Ket \\
\hline Ringan & 2 & 2 & Baik & \\
\hline Sedang & 2 & $3-4$ & Terganggu & $\begin{array}{l}\text { Nampak } \\
\text { distress }\end{array}$ \\
\hline Berat & 2 & $\geq 4$ & $\begin{array}{l}\text { Sangat } \\
\text { terngganggu }\end{array}$ & $\begin{array}{l}\text { Sangat } \\
\text { distress }\end{array}$ \\
\hline
\end{tabular}

\section{LAPORAN KASUS}

Pasien perempuan, suku melayu, berusia 37 tahun, sudah menikah, dating ke RSUPHAM Medan dengan keluhan mudah terbangun, adanya perasaan sedih yang mendalam, hilangnya semangat hidup, mudah merasalelah dan tidak ada selera makan. Pasien sering kali menyendiri dan gampang menangis. Gejalagejala tersebut muncul dalam waktu 3 bulan ini. 4 tahun yang lalu pasien mempunyai riwayat konsumsi steroid selama 2 tahun dengan dosis $\pm 20 \mathrm{mg} /$ hari. Saat itu pasien di diagnose Rhematoid Athritis. Pasien rutin makan obat, namun setelah 2 tahun mengkonsumsi steroid pasien menghentikan sendiri obatnya karena merasa sudah ada perbaikan. Kemudian 1 tahun belakangan ini pasien kembali berobat dengan diagnose Sistemik Lupus Eritematosus. Obat yang diberikan adalah obat steroid dengan dosis $\pm 60 \mathrm{mg} / \mathrm{hari}$.

Pasien merupakan anak paling besar dari 4 bersaudara. Pasien berlatar pendidikan diploma dan sebelum menikah pasien bekerja di Bank. Namun setelah berkeluarga pasien dilarang bekerja oleh suami. Pasien menikah pada usia 32 tahun dan saat ini sudah dikaruniai 2 orang anak. Suami pasien bekerja sebagai wirawasta.

Pada pemeriksaan fisik dijumpai: Vital sign: Kesadaran: CM TD: 110/70 mmHg, HR 88x/i, RR 20x/menit, Temp $37^{\circ} \mathrm{C}$.
Dari pemeriksaan kepala: mata: konjungtiva palpebral inferior pucat tidak dijumpai, sclera ikterik tidak dijumpai, thoraks: SP: vesikuler, ST: tidak dijumpai, abdomen: simetris, soepel, hepar/lien/renal tidak teraba, ekstremitas: edema tidak dijumpai.

Hasil Laboratorium:

$\mathrm{Hb} 11,8 \mathrm{~g} / \mathrm{dl}$, Leukosit 7500/mm3, trombosit 201.000/mm3, , Kalium 2,8, KGD AR 99 mg/dl SGOT 29 ,SGPT 32, Ureum 15,78 mg/dl, Cretinin 0,65 mg/dl.Colesterol total $198 \mathrm{mg} / \mathrm{dl}$, LDL 128 $\mathrm{mg} / \mathrm{dl}, \mathrm{HDL} 35 \mathrm{mg} / \mathrm{dl}$ Fotothoraks: Jantung dan Paru dalam batas normal, Foto Lumbo sakral: Spondilosis Lumbalis. EKG: Kesan: Sinus Ritme.

\section{DISKUSI}

Pada penyakit psiko somatic dipergunakan diagnosis berdasarkan multiaxial evaluation system yang dikenal dengan 5 aksis yaitu:

Aksis 1 : Faktor-factor psikologis yang mempengaruhi malfungsi atau kondisi fisik, sindrom klinis,

Aksis 2 : Gangguan (kepribadian) personality dan derajat beratnya gangguan tersebut,

Aksis 3 : Gangguan penyakit fisik,

Aksis 4 : Stressor psikososial dan derajat beratnya,

Aksis 5 : Sosio-kultural, kemampuan fungsi adaptasi yang tertinggi, didapatkan dalam 1 tahun terakhir.

Pada Kasus ini pasien berusia 37 tahun mengalami mood depresif yaitu keluhan mudah terbangun disertai adanya perasaan sedih yang mendalam, hilangnya semangat hidup, mudah merasa lelah dan tidak ada selera makan. Pasien sering kali menyendiri dan gampang menangis. Hal ini dialami pasien dalam 3 bulan belakangan. Riwayat penggunaan steroid yang lama dijumpai. Pasien merupakan anak paling besar. Seperti kita ketahui steroid merupakan pengobatan dalam jangka waktu panjang mempunyai efek samping berupa mood depresif.

Dengan menggunakan multiaxial evaluation system pada kasus ini adalah sebagai berikut:
Aksis 1 : Depresi
Aksis 2 : Belum dapat dinilai 


\begin{tabular}{c|c|c}
\hline JURNAL PENELITIAN FARMASI HERBAL & VOL. 1 NO. 2 & $\begin{array}{c}\text { EDITION: NOVEMBER 2018 - } \\
\text { APRIL 2019 }\end{array}$ \\
\hline RECEIVED: 17 FEBRUARI 2019 & http://ejournal.delihusada.ac.id/index.php/JPFH \\
\cline { 2 - 3 } & REVISED: 18 MARET 2019 & ACCEPTED: 20 APRIL 2019 \\
\hline
\end{tabular}

Aksis 3 : Sistemik Lupus Eritematosus

Aksis 4 : Faktor predisposisi pada pasien ini adalah pasien merupakan anak sulung dikeluarganya yang mana sering terabaikan karena pasien mempunyai adik 3 orang;

Faktor presipitasi pada pasien ini adalah pasien tidak diperbolehkan kerja oleh suami.

Aksis 5 : Sosial: buruk

Kinerja: buruk

Pemanfaatan waktu luang: buruk Kesimpulan: adaptasi buruk

Sesuai dengan konsep kedokteran psikosomatik pengobatan yang dilakukan selalu melihat semua aspek yang mempengaruhi timbulnya gangguan ini (aspek bio-psiko-sosio-spiritual). Pengobatan sesungguhnya harus dimulai sejak pasien bertemu dengan dokternya yaitu dengan memberikan perhatian atas keluhan-keluhan yang dikemukakan (Mudjaddid, 2009; Kaplan, 2000; Sharp, 2002).

Pemeriksaan fisik yang lengkap dan teliti harus dilakukan sehingga dapat member keyakinan pada pasien tentang penyakit yang sesungguhnya serta meyakinkan bahwa penyakitnya tidak separah yang dibayangkan pasien.

Obat-obatan diberikan sesuai dengan kelainan medis yang ditemukan dan simtomatis sesuai dengan gejala yang ada termasuk memberikan obat-obat psikofarmaka. Menganjurkan kebiasaan hidup sehat seperti makan, tidur, olahraga dan menjalankan hobi secara teratur. Psikoterapi (superficial) dimulai dengan menciptakan hubungan yang baik antara dokter-pasien, memberikan kesempatan mengutarakan konfliknya, mengutarakan isi hati (ventilasi). Dengan demikian pasien merasa puas dan lega serta berkurang ketegangannya. Melakukan reedukasi yaitu meluruskan pendapat-pendapat pasien yang salah atau kurang tepat dan member keyakinan pengertian tentang sebab-sebab penyakitnya.

Yang tidak kalah pentingnya ialah menekankan kembali komitmen agama dan pengamalannya, karena sudah terbukti bahwa individu yang kehidupan sehari-harinya tidak dilandasi etika dan moral agama ternyata sering mengalami kegagalan dan ketidak bahagiaan. Menolong menunjukkan jalan keluar dengan saran dan pandangan-pandangan sesuai kemampuan pasien, serta meningkatkan kemampuan penyesuaian diri terhadap lingkungan (Eisendrath, 2012).

Pada pasien ini dengan riwayat penggunaan steroid dalam waktu jangka lama sehingga menyebabkan depresi maka steroid dihentikan. Dilakukan psikoterapi superfisial dan reedukasi. Untuk psikofarmaka depresinya sendiri dapat digunakan antidepresan. Dalam kasus ini yang digunakan adalah golongan maprotilin selama 3 bulan sudah menunjukkan perbaikan yang signifikan.

Beberapa macam golongan anti depresan adalah golongan trisiklik dan tetrasiklik seperti: Amitriptilin, Imipramin, Mianserin dan Maprotilin. Golongan trisiklik sudah jarang dipakai karena memiliki efek samping yang banyak akibat kerja antikolinergiknya. Beberapa antidepresan yang baru dengan efek samping yang minimal ialah golongan obat sebagai berikut:

- Golongan SSRI (Selective Serotonin Reuptake Inhibitor): Sertralin, Paroksetin, Fluoksetin, Fluvoksamin.

- Golongan SSRE (Selective Serotonin Reuptake Enhancer): Tianeptin

- Golongan SNRI (Serotonin Nor Epinephrin Reuptake Inhibitor): Venlafaksin

- Golongan RIMA (Reversible Inhibitory Monoamine Oxidase type $A$ ): Moklobemid

- Golongan NaSSA (Nor adrenalin and Serotonin Selective Anti Depressant): Mirtazapin

- Golongan Atipik: Trazodon, Nefazodon.

Namun dalam penberian obat ini haruslah bersamaan dengan pemberian psikoterapi efektif sehingga hasilnya akan lebih baik (Qaseem, 2008).

\section{KESIMPULAN}

Telah dilaporkan kasus depresi induced steroid setelah dilakukan psikoterapi dan pemberian sandepril $2 \times 25 \mathrm{mg}$ kondisi pasien menunjukkan perbaikan. 


\begin{tabular}{c|c|c}
\hline JURNAL PENELITIAN FARMASI HERBAL & VOL. 1 NO. 2 & $\begin{array}{c}\text { EDITION: NOVEMBER 2018 - } \\
\text { APRIL 2019 }\end{array}$ \\
\hline RECEIVED: 17 FEBRUARI 2019 & http://ejournal.delihusada.ac.id/index.php/JPFH \\
\cline { 2 - 3 } & REVISED: 18 MARET 2019 & ACCEPTED: 20 APRIL 2019 \\
\hline
\end{tabular}

\section{DAFTAR PUSTAKA}

Mudjaddid E. 2009. Pemahaman dan penanganan psikosomatik gangguan ansietas dan depresi: di bidang ilmu penyakit dalam. (ED) Sudoyo A, Setiyohadi B. Alwi I, Simadibrata M, setiati $S$, editors. Buku ajar ilmu penyakit dalam edisi V. Jakarta :Interna Publishing: 210510

Reus V. 2012. Mental disorders. (Ed) Fauci A, Kasper $D$, Longo $D$, Braunwald $E$, Hauser $\mathrm{S}$, Jameson J, Loscalzo J, editors. Harrison's principles of internal medicine $18^{\text {th }}$ ed. Newyork: McGraw-Hill Medical Publishing Division; 3529 -43

Kaplan, H.I., Saddock, B.J. 2000. Mood disorder, comprehensive Textbook of Psychiatry, $7^{\text {th }} E D$. William \& Wilkins.

Sharp L, Lipsky M. 2002. Screening for depression across the lifespan: a review of measures for use in primary care settings. Am Fam Physician.66 (6): 10019

Eisendrath S, Lichtmacher J. 2012. Psychiatric disorders. In: Mcphee S, Papadakis M, Rabow M, editors. Current medical diagnosis and treatment 2012. $51^{\text {th }}$ ed. Asia; The Mcgraw-Hill Education. 1034-47

Qaseem A, Snow V. Denberg, TD, et al. 2008. Using Second-Generation Antidepressant to Treat Depressive Disorder: A Clinical Practice Guideline from the American College of Physicians. Ann Intern Med. 149: 725 - 733 